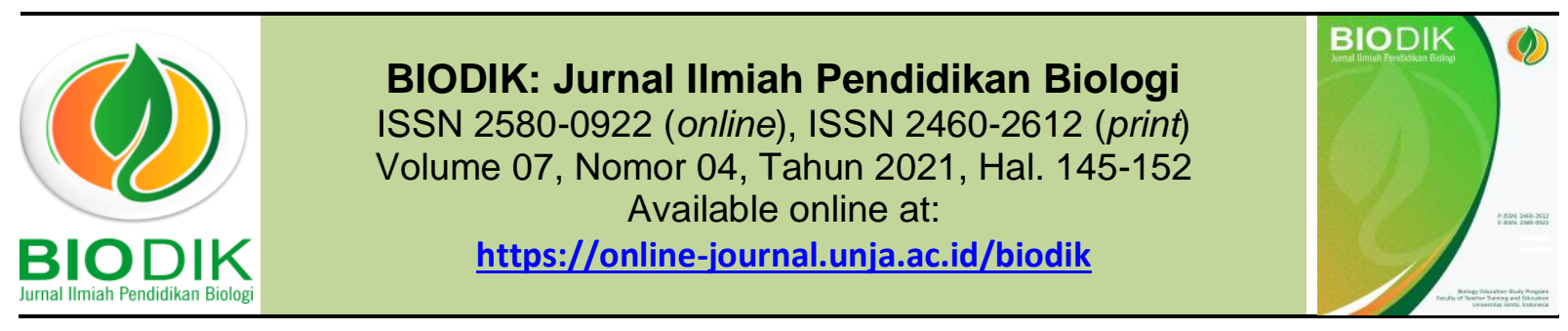

Research Article

\title{
Pengaruh Model Pembelajaran Kooperatif Think Talk Write Terhadap Aktivitas Belajar Biologi Siswa SMA
}

\section{(The Effect Of Think Talk Write Cooperative Learning Model on Biology Learning Activities in Senior High School Students)}

\author{
Try Susanti ${ }^{{ }^{*}}$, Rita Simatupang ${ }^{2}$, Dwi Gusfarenie ${ }^{3}$, Rahmat Hidayat ${ }^{4}$ \\ 1,2,3Program Studi Tadris Biologi UIN Sulthan Thaha Saifuddin Jambi \\ ${ }^{4}$ SMA Negeri 4 Tanjung Jabung Barat \\ ${ }^{*}$ Corresponding Author: trysusantiusman@gmail.com
}

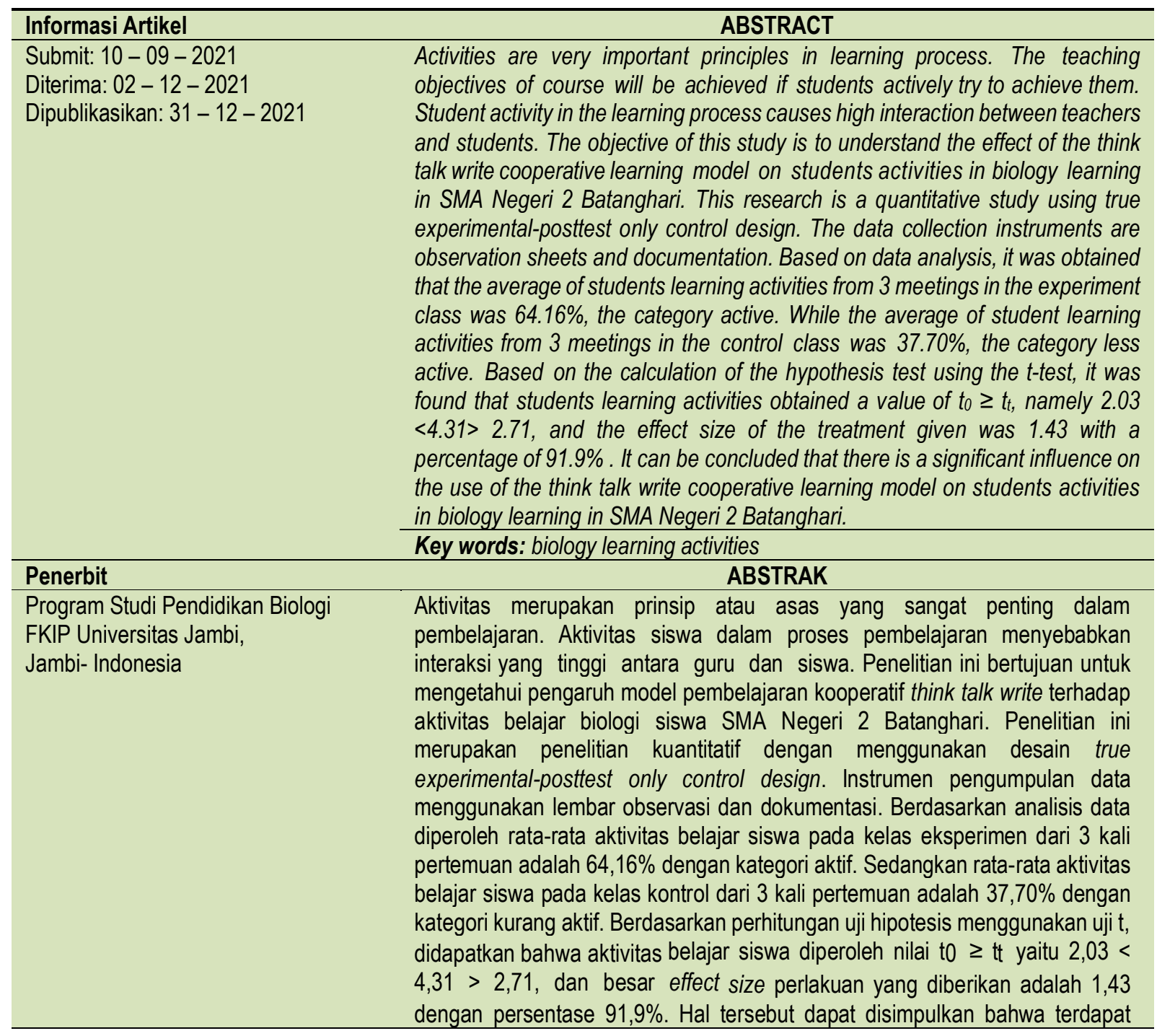


pengaruh yang signifikan dalam penggunaan model pembelajaran kooperatif think talk write terhadap aktivitas belajar biologi siswa SMA Negeri 2 Batanghari.

Kata kunci: think talk write, aktivitas belajar biologi

This BIODIK : Jurnal IImiah Pendidikan Biologi is licensed under a CC BY-NC-SA (Creative Commons Attribution-ShareAlike 4.0 International License)

\section{PENDAHULUAN}

Pembelajaran di sekolah merupakan rangkaian kegiatan interaktif antara siswa, guru, dan sumber belajar (Hidayat, 2020). Aktivitas merupakan prinsip atau asas yang sangat penting dalam interaksi tersebut. Saat pembelajaran berlangsung, siswa mampu memberikan umpan balik terhadap guru. Tujuan pembelajaran akan dapat dicapai jika siswa berusaha secara aktif untuk mencapainya. Dalam kegiatan belajar diperlukan keterlibatan unsur fisik, mental, intelektual, dan emosional sebagai wujud reaksi bahwa siswa belajar. Keaktifan siswa dalam proses pembelajaran menyebabkan interaksi yang tinggi antara guru dan siswa maupun sebaliknya antara siswa dan guru. Aktivitas atau keaktifan yang timbul dari siswa akan mengakibatkan terbentuknya pengetahuan dan keterampilan yang akan mengarahkan kepada prestasi belajar.

Aktivitas belajar terjadi dalam satu konteks perencanaan untuk mencapai suatu perubahan tertentu. Aktivitas ini menunjuk pada keaktifan seseorang dalam melakukan suatu kegiatan tertentu, baik pada aspek-aspek jasmani maupun mental yang memungkinkan terjadinya perubahan pada dirinya (Andriani dkk, 2016). Aktivitas belajar menggunakan seluruh potensi individu sehingga akan terjadi perubahan tertentu.dalam pembelajaran, siswa perlu mendapatkan kesempatan untuk melakukan aktivitas (Rusman, 2017).

Berdasarkan hasil observasi awal yang dilakukan peneliti pada mata pelajaran biologi di SMA negeri 2 Batanghari terdapat beberapa permasalahan yang ditemukan antara lain guru cenderung sering menggunakan metode ceramah pada proses pembelajaran dikarena sarana dan prasarana di sekolah yang belum memadai dengan model pembelajaran direct learning. Masalah tersebut menyebabkan siswa merasa bosan mengikuti proses pembelajaran sehingga siswa lebih senang bercerita dengan teman sebangkunya dibandingkan mendengarkan dan memperhatikan ketika guru menyampaikan materi pelajaran. Selain itu siswa kurang bersemangat dalam mengikuti proses pembelajaran dikarena kosentrasi siswa sudah berkurang disebabkan siswa mengantuk, dan akibatnya menyebabkan siswa malas untuk berdiskusi dan menulis materi pembelajaran yang disampaikan oleh guru.

Strategi pembelajaran yang tepat harus diterapkan untuk menyelesaikan masalah tersebut, khususnya dalam memperbaiki aktivitas belajar siswa. Karena aktivitas merupakan prinsip atau asas yang sangat penting dalam interaksi pembelajaran. Muara dari aktivitas tersebut ialah pencapaian kompetensi belajar. Nuraini, Fitriana, dan Fadhilah (2018) menyatakan bahwa ada hubungan yang signifikan antara aktivitas belajar dengan hasil belajar.

Berdasarkan permasalahan tersebut, peneliti memberi solusi yaitu dengan menggunakan model pembelajaran model Think Talk Write. Ansari \& Yamin (2012) menyatakan bahwa model pembelajaran Think Talk Write ini dapat mengaktifkan siswa ketika di kelas, sehingga suasana kelas saat proses belajar mengajar terasa tidak membosankan. Model think talk write adalah sebuah pembelajaran yang di mulai dengan berpikir melalui bahan bacaan (menyimak, mengkritisi, dan alternative solusi), hasil bacaannya di komunikasikan dengan presentasi, diskusi, dan kemudian membuat laporan hasil presentasi. Sintaknya adalah informasi, kelompok (membacamencatatmenandai), presentasi, diskusi, melaporkan.

Penggunaan model pembelajaran Think Talk Write ini diharapkan dapat dijadikan salah satu alternatif untuk memberikan rangsangan keaktifan siswa, mengatasi kesulitan siswa dalam memahami 
materi, menjadikan suasana yang ada di dalam kelas akan lebih menyenangkan dan menarik serta pembelajaran menjadi bervariasi sehingga meningkatkan aktivitas belajar.

\section{METODE PENELITIAN}

Penelitian dilaksanakan pada rentang Bulan September - November 2020 di SMA Negeri 2 Batanghari. Penelitian ini adalah penelitian eksperimen untuk mengetahui perbedaan aktivitas belajar biologi (Variabel dependent) siswa antara kelas yang menggunakan model pembelajaran kooperatif think talk write (Variabel Independent) dengan kelas yang melaksanakan pembelajaran konvensional. Dalam penelitian ini terdapat dua kelas yaitu kelas eksperimen yang diberi perlakuan menggunakan model pembelajaran Think Talk Write dan kelas kontrol yang menggunakan model konvensional. Pembelajaran dilaksanakan sebanyak 3 kali pertemuan tatap muka dengan alokasi waktu satu kali pertemuan adalah $2 \times 45$ menit.

Desain penelitian yang digunakan ialah desain True Experimental-Posttest Only Control Design. Sampel penelitian diambil 2 kelas dari 3 kelas XI IPA dengan teknik cluster random sampling. Sampel penelitian ialah 20 siswa kelas XI IPA 1 sebagai kelas eksperimen dan 20 siswa kelas XI IPA 2 sebagai kelas kontrol. Desain penelitian ini dapat dilihat pada tabel 1.

Tabel 1. Desain Penelitian Eksperimen

\begin{tabular}{cccc}
\hline Kelas & Jumlah Siswa & Perlakuan & Aktivitas belajar \\
\hline XIPA 1 & 20 & $X$ & Y1 \\
XIPA 2 & 20 & - & Y2 \\
\hline
\end{tabular}

Keterangan :

$X=$ Perlakuan dengan menggunakan model pembelajaran Think Talk Write

$\mathrm{Y}_{1}=$ Aktivitas belajar siswa dengan penerapan model pembelajaran Think Talk Write

$Y_{2}=$ Aktivitas belajar siswa yang tidak menerapkan model pembelajaran Think Talk Write

Metode pengumpulan data penelitian ialah observasi dan dokumentasi. Penulis melakukan observasi dibantu 2 orang observer untuk mengamati aktivitas belajar siswa selama proses pembelajaran berlangsung. Observer akan mengisi lembar observasi aktivitas belajar dengan indikator dapat dilihat pada tabel 2 .

Tabel 2. Indikator-indikator Aktivitas Belajar

\begin{tabular}{lll}
\hline No. & \multicolumn{1}{c}{ Indikator } & \multicolumn{1}{c}{ Aktivitas Siswa } \\
\hline $\mathbf{1}$ & Visual Activities & Membaca teks \\
\cline { 3 - 3 } & & Menghadiri presentasi atau demonstrasi \\
\hline $\mathbf{2}$ & Oral Activities & Merespons pertanyaan \\
\hline $\mathbf{3}$ & Listening Activities & Berwawancara diskusi dan interupsi \\
\cline { 3 - 3 } & Writing Activities & Mendengarkan penyajian bahan \\
\hline $\mathbf{4}$ & Drawing Activities & Membuat rangkuman \\
\hline $\mathbf{5}$ & Mengerjakan tes \\
\hline $\mathbf{6}$ & Motor Activities & Menggambar \\
\hline $\mathbf{7}$ & Mental Activities & Membuat peta konsep \\
\hline $\mathbf{8}$ & Emotional Activities & Melakukan percobaan \\
\hline & & Bergotong royong \\
\hline
\end{tabular}


Sumber : Sardiman (2011)

Kategori aktivitas siswa dimulai dari sangat aktif, aktif, kurang aktif dan tidak aktif. Untuk pengkategorian aktivitas belajar siswa digunakan skala interval dengan kategori dapat dilihat pada tabel 3.

Tabel 3. Kategori Aktivitas Belajar Siswa

\begin{tabular}{ccc}
\hline No. & Interval & Kategori \\
\hline 1 & $0 \%-25 \%$ & Tidak Aktif \\
\hline 2 & $26 \%-50 \%$ & Kurang Aktif \\
\hline 3 & $51 \%-75 \%$ & Aktif \\
\hline 4 & $76 \%-100 \%$ & Sangat Aktif \\
\hline Sumber: Arikunto (2010) &
\end{tabular}

Analisis data dilakukan secara kuantitatif, meliputi uji normalitas, uji homogenitas dan uji hipotesis. Kenormalan data diuji dengan uji liliefors (taraf signifikansi 5\%). Homogenitas data diuji dengan uji beda varians (taraf kepercayaan 95\%). Hipotesis diuji dengan uji t untuk data 2 sampel kecil yang satu sama lain tidak berhubungan. Semua analisis statistik dilakukan dengan menggunaan aplikasi Microsoft Excel. Adapun Hipotesis dalam penelitian ini ialah sebagai berikut,

$\mathrm{H}_{0} \quad=$ tidak ada pengaruh model pembelajaran think talk write terhadap aktivitas belajar biologi siswa SMA Negeri 2 Batanghari.

$\mathrm{H}_{\mathrm{a}} \quad=$ ada pengaruh model pembelajaran think talk write terhadap aktivitas belajar biologi siswa SMA Negeri 2 Batanghari.

\section{HASIL PENELITIAN DAN PEMBAHASAN}

Pelaksanaan penelitian pada kelas eksperimen dan kelas kontrol telah memperoleh beberapa hasil penelitian, mulai dari skor aktivitas belajar siswa, uji normalitas, uji homogenitas dan uji hipotesis. Hasil penelitian tersebut sebagaimana diuraikan berikut ini.

\section{Ativitas Belajar Siswa berdasarkan Observasi}

Aktivitas belajar diobservasi sebanyak jumlah pembelajaran yang dilaksanakan, yaitu tiga kali, baik di kelas eksperimen XI IPA 1 maupun di kelas kontrol XI IPA 2. Pembelajaran di elas eksperimen menggunakan pembelajaran think talk write sedangkan di kelas kontrol menggunakan pembelajaran konvensional. Berdasarkan hasil observasi untuk setiap indikator dan aktivitas siswa diperoleh data ratarata aktivitas belajar dapat dilihat pada gambar 1 .

\section{Persentase Aktivitas Siswa}

\section{$100.00 \%$}

$80.00 \%$

$60.00 \%$

$40.00 \%$

$20.00 \%$

$0.00 \%$

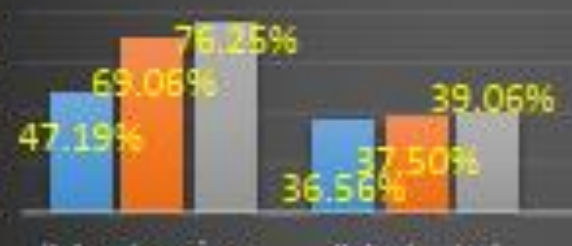

Kelas eksoerimen

Kelss bentrel

Eerteming 1 Dertemusn 2: Dertemuan 3

Gambar 1. Grafik rata-rata persentase aktivitas siswa kelas eksperimen dan kontrol 
Berdasarkan tabel tersebut dapat dilihat bahwa nilai rata-rata aktivitas belajar siswa pada kelas eksperimen XI IPA 1 dan kelas kontrol XI IPA 2 mengalami peningkatan pada setiap pertemuannya. Namun demikian, diagram tersebut menunjukan bahwa aktivitas belajar siswa di kelas kontrol tidak pernah lebih tinggi dari aktivitas belajar siswa di kelas eksperimen. Apabila persentase aktivitas setiap pertemuan dirata-rata, maka rata-rata aktivitas belajar siswa kelas eksperimen ialah $64,16 \%$ dan kelas kontrol $37,70 \%$, dengan selisih 26,46 poin.

Berdasarkan data hasil observasi, indikator visual activities berkategori aktif. Siswa antusias dalam memproses pembelajaran. Mereka aktif ketika mepresentasi hasil diskusi di depan kelas. Menurut Buzan (2005) bahwa Visual Activities dapat memberikan kesempatan siswa untuk membuka diri, berimajinasi, memahami, berpikir kreatif, menganalisis, dan mengekspresikan diri. Gaya belajar visual (penglihatan), yaitu gaya belajar dimana sesorang belajar dengan paling baik ketika mereka melihat gambar yang mereka pelajari, mereka berorentasi pada teks tercetak dan dapat belajar melalui membaca.

Hasil aktivitas siswa yang menggunakan model pembelajaran Think Talk Write dengan nilai tertinggi yaitu Oral Activities berkategori sangat aktif. Menurut Hamalik (2012) bahwa aktivitas siswa ketika pembelajaran nilainya lebih besar terhadap pengajaran. Hal tersebut dikarena siswa langsung mengalami sendiri dan mencari informasi atau pengalaman sendiri sehingga mereka dapat mengembangkan seluruh aspek pribadi secara integral, dan memupuk kerja sama yang harmonis dengan siswa yang lain. Ansari \& Yamin (2012) mengutarakan talk penting dalam belajar Biologi karena sebagai cara utama untuk berkomunikasi dalam diskusi, pembentukan ide (forming ideas) melalui proses talking, meningkatkan dan menilai kualitas berpikir karena talking dapat membantu mengetahui tingkat pemahaman siswa dalam belajar Biologi.

\section{Uji Normalitas}

Uji normalitas dilakukan dengan menganalisis nilai ulangan harian tahun ajaran 2020/2021 siswa kelas XI IPA. Tujuan melaksanakn uji normalitas adalah untuk melihat apakah sampel berdistribusi normal atau tidak. Penggunaan uji Liliefors disebabkan jumlah sampel kecil <30. Hasil uji normalitas menunjukkan data sebagai mana dapat dilihat pada tabel 4 .

Tabel 4. Hasil Uji Normalitas

\begin{tabular}{ccccccc}
\hline Kelas & $\begin{array}{c}\text { Jumlah } \\
\text { Siswa }\end{array}$ & Mean & $\begin{array}{c}\text { Standar } \\
\text { Deviasi }\end{array}$ & $L_{\text {hitung }}$ & $L_{\text {tabel }}$ & Keterangan \\
\hline Kelas XI IPA 1 & 20 & 82,85 & 6,86 & 0,1082 & 0,190 & Normal \\
\hline Kelas XI IPA 2 & 20 & 71,95 & 8,65 & 0,1599 & 0,190 & Normal \\
\hline
\end{tabular}

Berdasarkan tabel 4, pada kelas eksperimen XI IPA 1 skor mean 82,85; standar deviasi 6,86 dan

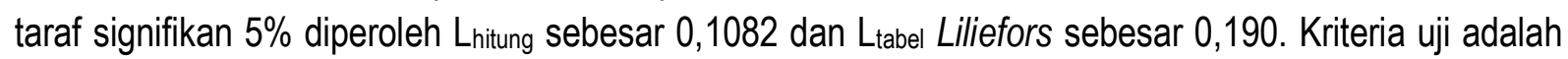
$L_{\text {hitung }}<L_{\text {tabel }}$ maka data berirdistribusi normal, maka diterima karena 0,1082 $<0,190$. Pada kelas kontrol XI IPA 2 skor mean 71,95; standar deviasi 8,95 dan taraf signifikan 5\% diperoleh Lhitung sebesar 0,1599 dan $L_{\text {tabel }}$ Liliefors sebesar 0,190 . Kriteria uji adalah $L_{\text {nitung }}<L_{\text {tabel }}$ maka data berirdistribusi normal, maka diterima karena $0,1599<0,190$. 


\section{Uji Homogenitas}

Uji homogenitas dilakukan untuk mengetahui kesamaan antara dua keadaan atau populasi. Untuk menguji homogenitas varian ini, Homogenitas yang digunakan menggunakan uji Beda Varians pada taraf kepercayaan $95 \%$. Hasil pengujian menunjukkan data sebagaimana dapat dilihat pada tabel 5.

Tabel 5. Hasil Uji Homogenitas

\begin{tabular}{|c|c|c|c|c|c|c|c|}
\hline Kelas & $\begin{array}{c}\text { Jumlah } \\
\text { Siswa }\end{array}$ & Mean & $\begin{array}{l}\text { Standar } \\
\text { Deviasi }\end{array}$ & $\mathrm{S}^{2}$ & $F_{\text {hitung }}$ & $F_{\text {tabel }}$ & Keterangan \\
\hline Kelas XI IPA 1 & 20 & 82,85 & 6,86 & 49,50 & & & \\
\hline Kelas XI IPA 2 & 20 & 71,95 & 8,65 & 78,79 & 1,59 & 2,16 & Homogen \\
\hline
\end{tabular}

Berdasarkan perhitungan uji homogenitas beda varians, diperoleh data pada kelas eksperimen XI IPA 1 skor mean sebesar 82,85; standar deviasi sebesar 6,86; sedangkan pada kelas kontrol XI IPA 2 skor mean sebesar 71,95; standar deviasi sebesar 8,65; varian terbesarnya adalah 49,50 dan varian terkecilnya 78,79. Diperoleh $F_{\text {hitung }}$ sebesar 1,59 dan $F_{\text {tabel }} 2,16$ dan tarif signifikan $5 \%$. Kriteria ujinya jika $F_{\text {hitung }}<F_{\text {tabel }}$ maka varian dinyatakan homogen. $F_{\text {hitung }} 1,59<F_{\text {tabel }} 2,16$, maka dapat disimpulkan bahwa tidak ada perbedaan varians antara kelas eksperimen dan kelas kontrol.

\section{Uji Hipotesis}

Uji hipotesis menggunakan uji t untuk data 2 sampel kecil yang satu sama lain tidak berhubungan, berbeda subjek penelitian antara kelas eksperimen dan kelas kontrol. Uji t ini dilakuan untuk mengetahui perbedaan antara skor aktivitas belajar siswa kelas eksperimen dengan kelas kontrol. Hasil pengujian menunjukkan data dapat dilihat pada tabel 6 .

Tabel 6. Hasil Uji Hipotesis

\begin{tabular}{|c|c|c|c|c|c|c|c|c|}
\hline Kelas & $\begin{array}{c}\text { Jumlah } \\
\text { Siswa }\end{array}$ & Mean & $\begin{array}{l}\text { Standar } \\
\text { Deviasi }\end{array}$ & $\mathrm{SE}_{\mathrm{M}}$ & $S E_{M x-M y}$ & $t_{0}$ & $t_{t}$ & d \\
\hline Kelas XI IPA 1 & 20 & 82,85 & 6,86 & 1,57 & & & $2,02(5 \%)$ & \\
\hline Kelas XI IPA 2 & 20 & 71,95 & 8,65 & 1,98 & 2,53 & 4,31 & $2,71(1 \%)$ & 1,43 \\
\hline
\end{tabular}

Karena $t_{0}$ atau $t_{\text {test }}$ yang diperoleh dalam perhitungan $t_{0}=4,31$ lebih besar dari pada $t_{\text {tabel }}$ baik pada taraf signifikan $5 \%$ ataupun $1 \%$ ), maka dari kedua hipotesis yang ada dapat disimpulkan Hipotesis Nihil ditolak, sedangkan Hipotesis Alternatif diterima, dengan kesimpulan terdapat pengaruh yang signifikan antara variabel $X$ terhadap variabel $Y$. Dengan kata lain, terdapat Pengaruh Model Pembelajaran Think Talk Write terhadap aktivitas Belajar Biologi Siswa SMA Negeri 2 Batanghari.

Untuk menghitung effect size pada uji $t$ digunakan rumus Cohen's. Berdasarkan hasil perhitungan, diperoleh besarnya effect size perlakuan yang diberikan adalah 1,43 dengan persentase 91,9\%. Hasil ini menunjukkan bahwa terjadi pengaruh yang tinggi dan konsisten dari pengaruh model pembelajaran Think Talk Write terhadap aktivitas belajar Biologi Siswa SMA Negeri 2 Batanghari.

Melalui penerapanmodel pembelajaran Think Talk Write (TTW), guru dapat mengetahui penguasaan peserta didik terhadap materi yang disampaikan dan mendorong peserta didik untuk berani mengajukan pendapatnya. Pembelajaran menjadi lebih menarik sehingga siswa lebih bersemangat dan 
termotivasi dalam kegiatan pembelajaran. Model pembelajaran Think Talk Write (TTW), dapat menjadikan aktivitas belajar siswa menjadi lebih baik. Karena model pembelajaran ini dapat mempertajam seluruh keterampilan berfikir kritis, mengembangkan pemecahan yang bermakna dalam rangka memahami materi ajar. Dengan diberikan soal siswa dapat mengembangkan keterampilan berfikir kritis dan kreatif siswa. Selain itu, dengan berinteraksi dan berdiskusi dengan kelompok akan melibatkan siswa secara aktif dalam belajar (Siswanto dan Ariani, 2016).

Model pembelajaran Think Talk Write (TTW) membiasakan siswa untuk berfikir dan berkomunikasi dengan teman, guru dan bahkan dengan diri mereka sendiri serta memberikan pembelajaran ketergantungan secara postiif. Dengan pembelajaran seperti itu, suasana menjadi rileks sehingga terjalinnya hubungan persahabatan antara siswa dan guru. Berbeda dengan pembelajaran yang dilakukan di kelas kontrol.Pada kelas kontrol, pembelajaran menggunakan metode ceramah sehingga siswa lebih banyak mendapatkan pengetahuan secara langsung dari penyampaian materi oleh guru dan juga buku.

Metode ceramah menurut Huda (2010) mengemukakan bahwa metode ceramah dapat diartikan sebagai cara menyajikan pelajaran melalui penuturan secara lisan atau penjelasan langsung kepada sekelompok siswa. Metode ceramah merupakan penerangan dan penuturan secara lisan oleh guru terhadap siswanya, dalam metode ini peran guru lebih dominan dibanding yang lebih mendominankan peran guru (Sanjaya, 2012). Sedangkan peran siswa hanya mendengarkan dan mencatat pokok bahasan yang di kemukan oleh guru. Hal ini dikarenakan guru menyampaikan materi secara keseluruhan termasuk dalam pemberian contoh soal. Untuk menghindari kebosanan siswa dalam belajar guru melakukan tanya jawab dengan siswa. Dalam hal ini, peran siswa yang terlihat hanyalah menerima pelajaran dari apa yang disampaikan oleh guru saja.

\section{SIMPULAN}

Aktivitas belajar siswa di kelas eksperimen memiliki skor rata-rata $64,16 \%$ dengan kategori aktif, sedangkan aktivitas belajar siswa di kelas eksperimen memiliki skor rata-rata 37,70\% dengan kategori kurang aktif. Berdasarkan perhitungan uji hipotesis menggunakan uji t, didapatkan bahwa aktivitas belajar siswa diperoleh nilai to $\geq$ tt yaitu 2,03 $<4,31>2,71$, dan besar effect size perlakuan yang diberikan adalah 1,43 dengan persentase $91,9 \%$. Hal tersebut dapat disimpulkan bahwa terdapat pengaruh yang signifikan dalam penggunaan model pembelajaran kooperatif think talk write terhadap aktivitas belajar biologi siswa SMA Negeri 2 Batanghari.

\section{RUJUKAN}

Andriani, E., Sumarmi \& I.K. Astina (2016). Peningkatan kompetensi pedagogik guru dan kemampuan akademik siswa melalui lesson study. Jurnal Pendidikan: Teori, Penelitian, dan Pengembangan, 1(11), 2106-2112.

Ansari, B.I. \& M. Yamin (2012). Taktik mengembangkan kemampuan individual siswa. Jakarta: GP Press Group.

Hamalik, O. (2012). Proses Belajar Mengajar. Jakarta: PT. Bumi Aksara

Hidayat, R. (2020). Studi Pendahuluan tentang Dampak Penerapan Model Pembelajaran CCTT terhadap Aktivitas Belajar Biologi. Biodik: Jurnal IImiah Pendidikan Biologi, 6(1), 23-34.

Huda. (2010). Cooperative Learning. Yogyakarta: Pustaka Belajar.

Nuraini, Fitriana, \& Fadhilah, R. (2018). Hubungan antara Aktivitas Belajar Siswa dan Hasil Belajar pada Mata Pelajaran Kimia Kelas X SMA Negeri 5 Pontianak. ArRazi Jurnal IImiah, 6(1), 30-39. 
BIODIK: Jurnal IImiah Pendidikan Biologi

Vol. 07, No. 04 (2021), Hal. 145 - 152

Rusman, (2017). Belajar dan Pembelajaran Berorientasi Standar Proses Pendidikan. Jakarta: Kencana.

Sanjaya, W. (2012). Strategi Pembelajaran Berorientasi Standar Proses Pendidikan. Jakarta: Kencana.

Sardiman AM. (2011). Interaksi dan Motivasi Belajar-Mengajar. Jakarta : PT Raja Grafindo Persada. Wahyudi, S. \& A. Dewi. (2016). Model Pembelajaran Menulis Cerita. Bandung: Reflika Aditama. 